\title{
PEMBELAJARAN BAHASA DAERAH GORONTALO PADA ANAK USIA DINI
}

\author{
Wenny Hulukati, Maryam Rahim, \& Yusuf Djafar \\ e-mail: wennyhulukati@ung.ac.id \\ Universitas Negeri Gorontalo \\ JI. Jenderal Sudirman No. 6, Gorontalo
}

\begin{abstract}
Abstrak: Penanaman dan pelestarian nilai budaya dapat dilakukan antara lain melalui penggunaan bahasa daerah di kalangan masyarakat. Akan tetapi, dewasa generasi muda cenderung kurang menguasai dan menggunakan bahasa daerah. Tulisan ini membahas pentingnya mendidik anak sedini mungkin menggunakan serta mencintai bahasa daerahnya. Pembelajaran bahasa daerah, dalam hal ini, bahasa daerah Gorontalo di lembaga pendidikan usia dini kurang terstruktur sehingga anak tidak terampil menggunakan bahasa daerah Gorontalo. Dengan melakukan berbagai kajian pustaka, tulisan mengajukan gagasan bagaimana membelajarkan anak usia dini sehingga mampu menggunakan bahasa daerah Gorontalo sebagai alat komunikasi. Tulisan ini juga menyarankan perlunya disusun pedoman pembelajaran yang jelas yang sesuai dengan karakteristik perkembangan anak usia dini.
\end{abstract}

Kata-kata kunci: pembelajaran, bahasa daerah Gorontalo, anak usia dini

\section{LEARNING GORONTALO LOCAL LANGUAGE FOR EARLY-AGED CHILDREN}

\begin{abstract}
Local language is one of the characteristics as well as a cultural richness of an area that needs to be preserved existence. In Gorontalo, some teenagers are not confident in their local languages, and children who are unable to communicate with Gorontalo language even in very simple contexts, especially people in urban areas. Learning local languages of Gorontalo at the level of Early Childhood Education is considered to be one solution, considering the early age is a potential moment to develop various potentials, including the potential for language. Conditions encountered in early childhood education institutions show that learning / language activities in Gorontalo are not structured, resulting in the development of Gorontalo language ability in children is very low. For that reason, learning language of Gorontalo in early childhood needs to be organized in a systematic and structured based on clear guidelines. These guidelines include: (a) learning programs that are appropriate to the characteristics of early childhood development, (b) learning materials appropriate to the characteristics of early childhood development, and (c) evaluation guidelines that can clearly measure the development of local language skills in children aged early.
\end{abstract}

Keywords: learning, local language of Gorontalo, early childhood

\section{PENDAHULUAN}

Bahasa daerah merupakan salah satu ciri khas dan kekayaan budaya daerah yang perlu dilestarikan keberadaannya. Pelestarian yang dimaksud dilakukan dalam bentuk penggunaan bahasa daerah dalam komunikasi sehari-hari oleh anggota masyarakat daerah itu sendiri. Gorontalo merupakan salah satu dari sembilan daerah adat di Indonesia, juga memiliki bahasa daerah sebagai ciri khas daerah yang disebut bahasa Gorontalo. Sebagai bahasa daerah, tentu saja bahasa ini menjadi alat komunikasi warga masyarakat
Gorontalo, dari anak-anak hingga orang tua.

Fenomena yang tampak di kalangan masyarakat Gorontalo adalah ketidakmampuan masyarakat Gorontalo terutama anak-anak dan remaja dalam menggunakan bahasa daerah Gorontalo sehari-hari. Lebih memprihatinkan, adanya kenyataan sebagian remaja terutama di daerah perkotaan merasa tidak percaya diri, bahkan dapat dikatakan malu menggunakan bahasa Gorontalo. Sering terjadi, remaja yang menggunakan bahasa Gorontalo dianggap sebagai sesuatu yang 
langka oleh teman-temannya. Mereka lebih banyak menggunakan bahasa Indonesia. Berdasarkan pengamatan dalam kehidupan sehari-hari pada mahasiswa asal Gorontalo, hampir tidak pernah terdengar mereka menggunakan bahasa Gorontalo dalam komunikasi di kampus. Kondisi yang sama teramati di kalangan siswa SD, SMP, dan SMA.

Sikap pengguna bahasa yang buruk dapat digambarkan dengan rasa ketidakbanggaan terhadap bahasa yang menunjukkan adanya kondisi lunturnya kebanggaan berbahasa Gorontalo pada penutur asli Gorontalo (Baruadi, 2014). Realita menunjukkan gejala kepunahan bahasa Gorontalo dan kesempatan anak-anak belajar bahasa Gorontalo di lingkungan masyarakat bahkan keluarga relatif sedikit, mengingat orang tua lebih banyak menggunakan bahasa Indonesia dalam berkomunikasi. Jika kondisi tersebut tidak dicarikan solusinya maka dikhawatirkan bahasa daerah Gorontalo akan hilang dengan sendirinya.

Berbagai usaha telah dilakukan oleh pemerintah kota Gorontalo untuk melestarikan bahasa daerah Gorontalo, terutama penggunaannya oleh anak-anak dan remaja, antara lain melalui program siaran bahasa Gorontalo di Radio Republik Indonesia (RRI) Gorontalo, kurikulum muatan lokal bahasa daerah Gorontalo yang diajarkan di sekolah-sekolah, termasuk di lembaga PAUD, namun semua usaha ini belum memberikan hasil yang diharapkan. Terkait dengan masalah ini maka kegiatan pengembangan/ pembelajaran bahasa daerah Gorontalo yang dilaksanakan secara terprogram di tingkat Pendidikan Anak Usia Dini menjadi salah satu solusi.

Pendidikan Anak Usia Dini (PAUD) merupakan pendidikan yang paling mendasar dan menempati posisi yang sangat strategis dalam pengembangan sumber daya manusia, mengingat anak usia dini merupakan investasi yang sangat besar bagi keluarga dan juga bangsa. Berbagai hasil penelitian menunjukkan usia dini merupakan masa yang sangat penting bagi pendidikan anak. Pada masa tersebut tempaan dapat memberikan bekas yang kuat dan tahan lama. Kesalahan menempa memberikan efek negatif berkepanjangan yang sulit diperbaiki (Rousseau, dalam Pasaribu dan Simandjuntak, 1992).

Pendapat Rousseau tersebut menunjukkan betapa pentingnya pendidikan pada masa usia dini, sebab akan memberikan bekas yang kuat pada diri anak. Oleh sebab itu, dasar-dasar ke arah perkembangan sikap, pengetahuan dan keterampilan yang diperlukan bagi anak usia dini pada perkembangan selanjutnya perlu di tanamkan secara kontinu melalui aktivitas yang sistematis. Undang-Undang Republik Indonesia Nomor 20 Tahun 2003 tentang Sistem Pendidikan Nasional, Bab I, Pasal 1, Butir 14, menyatakan bahwa pendidikan anak usia dini adalah salah satu upaya pembinaan yang ditujukan kepada anak sejak lahir sampai dengan usia 6 tahun yang dilakukan melalui pemberian rangsangan pendidikan untuk membantu pertumbuhan dan perkembangan jasmani dan rohani agar anak memiliki kesiapan dalam memasuki pendidikan lebih lanjut.

Berdasarkan beberapa pendapat yang telah diungkapkan, diasumsikan jika sejak dini, anak-anak sudah dibelajarkan dan dibiasakan, serta dibangkitkan motivasinya untuk memiliki kebanggaan berbahasa daerah Gorontalo, maka upaya menjadikan bahasa daerah Gorontalo sebagai bahasa komunikasi sehari-hari di kalangan anakanak dan remaja, dan pelestarian bahasa daerah ini akan memberikan hasil yang diharapkan.

\section{PEMBAHASAN}

\section{Bahasa Daerah sebagai Muatan Lokal di PAUD}

Kurikulum muatan lokal merupakan salah satu solusi dalam melestarikan potensi daerah melalui pendidikan formal. Salah satu potensi daerah yang dikembangkan melalui kurikulum muatan lokal adalah bahasa daerah. Bahasa daerah adalah bahasa yang lazim dipakai dalam satu daerah. Pengembangan bahasa daerah melalui penerapan muatan lokal sangat berperan dalam mengakrabkan anak/siswa dengan bahasa daerahnya sendiri, di samping untuk memelihara kelestarian bahasa daerah itu sendiri (Pateda dan Pulubuhu, 2008). Hal ini sangat penting mengingat adanya anggota masyarakat suatu daerah termasuk kalangan anak/ siswa yang enggan untuk menggunakan bahasa daerahnya, bahkan hampir-hampir tidak memahami makna-makna yang terkandung dalam bahasa daerahnya itu apalagi menggunakannya.

Hasil dari suatu penelitian menunjukkan semakin rendahnya penguasaan bahasa daerah 
Gorontalo oleh generasi muda Gorontalo. Sebagian dari mereka hanya mampu memahami apa yang diucapkan orang lain, tetapi sulit menggunakannya secara lisan. Sebagian lagi tidak dapat memahami, serta tidak mampu menggunakannya dalam komunikasi sehari-hari (Fatmah, 1994). Hasil penelitian yang telah dilaksanakan kurang lebih 20 tahun yang lalu ini, jika dianalisis ternyata tidak jauh berbeda dengan kondisi sekarang, bahkan diduga kondisinya menjadi lebih memprihatinkan. Hal ini didasari oleh pemikiran semakin bervariasinya media yang memberi peluang berkembangnya bahasa prokem di kalangan generasi muda, dan di sisi lain mempersempit peluang penggunaan bahasa daerah. Hal tersebut dipertegas dengan realita bahwa dewasa ini sangat sedikit warga masyarakat Gorontalo utamanya anak-anak dan remaja, bahkan orang tua khususnya di perkotaan yang menggunakan bahasa Gorontalo dalam komunikasi sehari-hari. Jika kondisi seperti sekarang ini dibiarkan berlarut-larut maka bahasa Gorontalo akan mengalami kepunahan (Baruadi, 2014).

Anak sebagai bagian dari komunitas suatu masyarakat tentu saja turut bertanggung jawab atas kelestarian bahasa daerahnya. Oleh sebab itu, bahasa daerah sangat patut untuk dimasukkan ke dalam kurikulum sekolah dalam bentuk kurikulum muatan lokal, termasuk kurikulum PAUD. Kurikulum muatan lokal yang telah dikembangkan perlu diimplementasikan lebih lanjut berdasarkfan prinsipprinsip pembelajaran yang benar sehingga akan memberikan hasil yang diharapkan. Gejala yang tampak di lapangan menunjukkan pelaksanaan kurikulum muatan lokal tidak dilaksanakan secara terprogram sehingga hasilnya juga tidak bisa diukur.

Implementasi kurikulum dapat diartikan sebagai aktualisasi kurikulum tertulis (written curriculum) dalam bentuk pembelajaran. Implementasi kurikulum adalah operasionalisasi kurikulum yang masih bersifat potensial (tertulis) menjadi aktual dalam bentuk kegiatan pembelajaran (Mulyasa, 2002). Saylor (1983) mengatakan bahwa: "Instructions is thus the implementation of curriculum plan, usually, but not necessarity, involving teaching in the sense of student, teacher interaction in an educational setting".

Implementasi kurikulum akan sangat dipengaruhi oleh berbagai faktor, yakni (1) karakteristik kurikulum, yang mencakup ruang lingkup ide baru suatu kurikulum dan kejelasannya bagi pengguna di lapangan; (2) karakteristik pengguna kurikulum; dan (3) strategi implementasi, yaitu strategi yang digunakan dalam implementasi, seperti penyediaan perangkat kurikulum, dan perangkat pembelajaran.

Perangkat pembelajaran merupakan kesatuan komponen pembelajaran yang terdiri dari panduan guru, bahan ajar, dan panduan evaluasi. Bahan ajar adalah bahan-bahan atau materi pembelajaran yang disusun secara sistematis yang digunakan guru dan siswa dalam proses pembelajaran (Pannen dan Purwanto, 1994). Bahan ajar mempunyai struktur dan urutan yang sistematis, menjelaskan tujuan pembelajaran yang akan dicapai, memotivasi siswa untuk belajar, mengantisipasi kesulitan belajar siswa, memberikan rangkuman, memberikan latihan, dan secara umum berorientasi pada siswa secara individual (learner oriented). Biasanya bahan ajar dapat dipelajari siswa secara mandiri, karena sistematis dan lengkap. Hal-hal yang disebutkan ini sekaligus menjadi syarat sebuah bahan ajar yang baik, di samping menarik, memudahkan siswa belajar dan memilki tingkat keefektifan yang tinggi (Degeng dan Miarso, 1993; Percival dan Ellington, 1988; Danim, 2008).

\section{Karakteristik Perkembangan Anak Usia Dini}

Perkembangan merupakan proses yang bersifat kumulatif, yang berarti perkembangan terdahulu akan menjadi dasar bagi perkembangan selanjutnya. Hal ini berarti apabila terjadi hambatan pada perkembangan terdahulu maka perkembangan selanjutnya cenderung akan mengalami hambatan. Perkembangan masa usia dini merupakan dasar bagi perkembangan individu di masa selanjutnya, oleh sebab itu usia dini menjadi masa yang sangat penting bagi perkembangan individu.

Anak usia dini (usia 0-6 tahun) berada pada masa keemasan. Montessori dan Hainstock mengatakan bahwa masa ini merupakan periode sensitif, selama masa inilah anak secara khusus mudah menerima stimulus-stimulus dari lingkungannya. Pada masa ini, anak siap melakukan berbagai kegiatan dalam rangka memahami dan menguasai lingkungannya. Usia keemasan merupakan masa di mana anak mulai peka untuk menerima berbagai stimulasi dan berbagai upaya pendidikan dari lingkungannya baik disengaja maupun tidak disengaja. Pada masa peka inilah terjadi pematangan fungsi-fungsi fisik dan psikis sehingga anak siap merespons dan mewujudkan 
semua tugas-tugas perkembangan yang diharapkan muncul pada pola perilakunya sehari-hari (Montessori dalam Suparti, 2004).

Menurut teori perkembangan anak, diyakini bahwa setiap anak lahir dengan berbagai kemampuan. Kemampuan tersebut bersifat potensial dan diibaratkan belum muncul di atas permukaan. Untuk itulah, anak perlu diberikan pendidikan yang sesuai dengan perkembangannya dengan cara memperkaya lingkungan bermainnya. Artinya, orang dewasa perlu memberi peluang kepada anak untuk mewujudkan diri, berekspresi, berkreasi, dan menggali sumber-sumber terunggul yang tersembunyi dalam diri anak.

Berdasarkan tinjauan aspek pedagogis, masa usia dini merupakan masa peletak dasar atau pondasi awal bagi pertumbuhan dan perkembangan selanjutnya. Diyakini oleh sebagian besar pakar bahwa masa kanak-kanak yang bahagia merupakan dasar bagi keberhasilan di masa datang dan sebaliknya. Untuk itu, agar pertumbuhan dan perkembangan tercapai secara optimal, maka dibutuhkan situasi dan kondisi yang kondusif pada saat memberikan stimulasi dan upaya pendidikan yang sesuai dengan kebutuhan dan minat anak (Hulukati, 2012).

Perkembangan anak usia dini meliputi berbagai aspek, di mana aspek-aspek itu hanya dapat dibedakan dan tidak dapat dipisahkan. Menurut para ahli, aspek perkembangan itu meliputi lima kategori sebagai berikut.

Pertama, perkembangan motorik. Proses tumbuh kembang kemampuan gerak anak disebut perkembangan motorik. Pendapat lain mengemukakan bahwa perkembangan motorik berarti pengembangan pengendalian gerakan jasmani melalui kegiatan pusat saraf, urat saraf, dan otot yang terkoordinasi (Hurlock, 1980). Perkembangan motorik ada dua bentuk, yaitu (1) perkembangan motorik kasar dan (2) perkembangan motorik halus. Keterampilan motorik kasar adalah gerakan yang terjadi karena adanya koordinasi otot-otot besar seperti berjalan, melompat berlari, melempar, dan menaiki. Sedangkan keterampilan motorik halus adalah gerakan yang dilakukan dengan menggunakan otot halus seperti menggambar, menggunting, dan melipat kertas. Keterampilan halus merupakan keterampilan menggunakan jari-jari tangan serta pergelangan tangan dengan tepat. Penguasaan keterampilan motorik halus sama pentingnya dengan penguasaan keterampilan motorik kasar.

Kedua, perkembangan kognitif. Perkembangan kognitif meliputi aspek-aspek struktur intelektual yang dipergunakan untuk mengetahui sesuatu (Gunarsa dalam Dewi, 2005). Dengan demikian, kognitif adalah fungsi mental yang meliputi persepsi, pikiran, simbol, penalaran, dan pemecahan masalah. Perwujudan fungsi kognitif dapat dilihat dari kemampuan anak dalam menggunakan bahasa dan menyelesaikan soal angka-angka (Wieman dalam Dewi, 2005). Depdiknas (2002) menjelaskan bahwa kemampuan kognitif adalah kemampuan berpikir logis dan kritis, memberi alasan, memecahkan masalah, dan menemukan hubungan sebab akibat.

Piaget sebagai tokoh perkembangan kognitif mengemukakan bahwa perkembangan kognitif dibagi dalam empat tahap yaitu sensori motorik (024 bulan), pra operasional (2-7 tahun), operasional konkret (7-11 tahun), dan operasional formal (11 tahun ke atas). Sesuai dengan penggolongan teori Piaget, anak pada program PAUD berada pada tahapan pra-operasional. Pada usia ini, penguasaan bahasa yang sistematis, imitasi serta pikiran mulai berfungsi. Semua proses ini menunjukkan bahwa anak sudah mampu untuk melakukan tingkah laku simbolik. Berpikir pra-operasional dicirikan dengan mampu meniru, antisipasi, egosentris, dan memusat pada satu dimensi.

Ketiga, perkembangan bahasa. Bahasa diartikan sebagai suatu sistem simbol dan urutan kata-kata yang dapat digunakan untuk berkomunikasi dengan orang lain yang bersifat tak terbatas, general (berlaku umum), dan sesuai sistem aturan yang berlaku. Perkembangan bahasa anak dibagi dalam fase pra-linguistik dan fase linguistik. Fase pralinguitik adalah perkembangan bahasa anak usia 0-1 tahun, yaitu mulai sejak tangisan pertama sampai anak selesai dengan fase mengoceh. Sementara fase linguistik terjadi sejak anak berusia 1 tahun sampai dengan lima tahun, yaitu dari mengucap kata-kata pertama sampai dapat berbicara dengan lancar (Dewi, 2005). Periode linguistik dibagi dalam tiga tahap, yaitu (1) fase satu kata atau holofrase, (2) fase lebih dari satu kata, dan (3) fase diferensiasi. Menurut Ramirez \& Kuhl (2016), anak telah mampu belajar berbahasa sejak tahun pertama dalam kehidupannya.

Keempat, perkembangan sosial-emosional. Perkembangan sosial yang dimaksud adalah 
perolehan kemampuan perilaku yang sesuai dengan tuntutan sosial. Hal ini dapat dilihat dari proses kemampuan anak untuk bergaul dengan orang-orang di sekitarnya. Perkembangan sosial merupakan proses belajar menyesuaikan diri dengan norma-norma kelompok dan adat kebiasaan, belajar bekerjasama, saling berhubungan, dan merasa bersatu dengan orang-orang di sekitarnya (Hurlock, 1980). Selain itu, perkembangan sosio-emosional juga merupakan kemampuan mengadakan hubungan dengan orang lain, terbiasa untuk bersikap sopan santun, mematuhi peraturan dan disiplin dalam kehidupan sehari-hari dan dapat menunjukkan reaksi emosi yang wajar.

Kelima, perkembangan moral. Moral berasal dari kata "mores" yang berarti tata cara kebiasaan dan adat. Perilaku moral berarti perilaku yang sesuai dengan kode moral kelompok sosial. Perilaku tak bermoral adalah perilaku yang tidak sesuai dengan harapan masyarakat. Perilaku yang demikian bukan disebabkan ketidakacuhan akan harapan masyarakat, melainkan ketidaksetujuan dengan standar sosial atau kurang adanya perasaan wajib menyesuaikan diri. Perilaku amoral lebih disebabkan ketidakacuhan terhadap kelompok sosial dari pada pelanggaran sengaja terhadap standar kelompok. Perilaku anak kecil lebih pada moral dari pada amoral.

Memperhatikan aspek-aspek perkembangan anak usia dini, khususnya perkembangan kognitif dan perkembangan bahasa, jelaslah bahwa anakanak usia dini sangat potensial untuk belajar bahasa. Mereka dengan mudah menyerap berbagai simbol termasuk simbol-simbol bahasa, di mana hasil ini akan dipertahankan dalam waktu yang lama hingga ke fase perkembangan berikutnya. Oleh sebab itu, sangat tepat apabila bahasa daerah Gorontalo dibelajarkan kepada anak usia dini. Hal ini lebih beralasan lagi apabila dikaitkan dengan posisi PAUD sebagai peletak dasar bagi pendidikan anak.

Berdasarkan Undang-Undang Republik Indonesia Nomor 20 Tahun 2003 Tentang Sistem Pendidikan Nasional Bab I, Pasal I, Butir 14 dinyatakan bahwa: "Pendidikan Anak Usia Dini adalah suatu upaya pembinaan yang ditujukan kepada anak sejak lahir sampai dengan usia enam tahun yang dilakukan melalui pemberian rangsangan pendidikan untuk membantu pertumbuhan dan perkembangan jasmani dan rohani agar anak memiliki kesiapan dalam memasuki pendidikan lebih lanjut".

Selanjutnya, pada pasal 28 tentang Pendidikan Anak Usia Dini menyatakan bahwa (1) pendidikan anak usia dini diselenggarakan sebelum jenjang pendidikan dasar; (2) pendidikan anak usia dini dapat diselenggarakan melalui jalur pendidikan formal, non formal, dan/atau informal; (3) pendidikan anak usia dini jalur pendidikan formal: TK, RA, atau bentuk lain yang sederajat; (4) pendidikan anak usia dini jalur pendidikan nonformal: pendidikan keluarga atau pendidikan yang diselenggarakan oleh lingkungan, dan (5) ketentuan mengenai Pedidikan Anak Usia Dini sebagaimana dimaksud dalam Ayat (1), Ayat (2), Ayat (3), dan Ayat (4) diatur lebih lanjut dengan Peraturan Pemerintah.

\section{Pembelajaran Bahasa Daerah Gorontalo pada}

\section{Anak Usia Dini}

Dengan memperhatikan karakteristik perkembangan bahasa anak usia dini, maka dapat disimpulkan bahwa anak usia dini sangat potensial dalam belajar bahasa. Pada tahun-tahun pertama dalam kehidupannya, anak telah belajar bahasa. Pembelajaran di lembaga Pendidikan Anak Usia Dini dalam hal ini Taman Kanak-Kanak dilaksanakan dalam enam bidang pengembangan, yakni (1) pengembangan fisik, (2) pengembangan kognitif, (3) pengembangan bahasa, (4) pengembangan sosial emosional, (5) pengembangan moral dan agama, serta (6) pengembangan seni.

Kegiatan pembelajaran di taman kanak-kanak dan pendidikan anak usia dini pada umumnya, secara keseluruhan dimaksudkan untuk menstimulasi berbagai potensi yang dimiliki anak sehingga akan mengalami perkembangan secara optimal sebagai dasar untuk perkembangan di fase-fase selanjutnya. Salah satu potensi yang dikembangkan itu adalah potensi berbahasa, termasuk potensi berbahasa daerah di mana anak itu hidup dan berkembang. Bagi anak usia dini di daerah Gorontalo, maka upaya menstimulasi perkembangan bahasa anak diharapkan sekaligus dapat mengstimulir perkembangan kemampuan berbahasa daerah Gorontalo.

Agar pembelajaran bahasa daerah Gorontalo pada anak usia dini dapat memberikan kesempatan yang luas dan terstruktur bagi berkembangnya kemampuan berbahasa daerah Gorontalo, maka kegiatan tersebut perlu diselenggarakan secara sistematis dan terstruktur berdasarkan pedoman yang jelas. Pedoman dimaksud meliputi (1) 
program pembelajaran yang sesuai dengan karakteristik perkembangan anak usia dini, (2) materi pembelajaran yang sesuai dengan karakteristik perkembangan anak usia dini, dan (3) panduan evaluasi yang dapat mengukur dengan jelas perkembangan kemampuan berbahasa daerah pada anak usia dini.

1. Program pembelajaran bahasa daerah Gorontalo

Program pembelajaran bahasa daerah hendaknya sesuai dengan karakteristik perkembangan bahasa anak usia dini. Perkembangan bahasa anak terdiri atas fase prelinguistik dan fase linguistik (Dewi, 2005). Fase linguistik berlangsung pada usia 1-5 tahun, yakni mulai dari mengucap kata-kata pertama sampai dapat berbicara dengan lancar. Fase linguistik dibagi atas tiga fase besar.

Pertama, fase satu kata atau holofrase. Pada fase ini anak menggunakan satu kata untuk menyatakan sustu pikiran yang kompleks, baik berupa keinginan, perasaaan, atau kemauannya tanpa perbedaan yang jelas. Misalnya kata "duduk", dapat berarti "saya mau duduk", atau "kursi tempat duduk", atau "ibu duduk". Orang tua harus mengamati mimik, gerak gerik serta bahasa tubuh yang lain untuk memperjelasnya. Kata pertama yang dikuasai anak berupa kata benda yang selanjutnya anak menguasai kata kerja.

Kedua, fase lebih dari satu kata. Pada fase ini anak dapat membuat kalimat yang terdiri atas dua kata. Ada pokok kalimat dan ada predikat, kadangkadang objek tetapi dengan tata bahasa yang tidak selalu benar. Pada periode ini bahasa yang digunakan tidak bersifat egosentris, yaitu dari dan untuk dirinya. Komunikasi dengan orang lain mulai lancar, mulai tanya jawab yang sederhana, anak mulai bercerita dengan kalimat sederhana.

Ketiga, fase diferensiasi. Usia anak 2,5 - 5 tahun keterampilan anak berbicara berkembang pesat. Bukan saja penambahan kosa kata, tapi anak sudah mampu mengucap kata demi kata sesuai dengan jenisnya, terutama pemakaian kata benda dan kata kerja. Anak mampu menggunakan kata ganti orang "saya" untuk menyebut dirinya. Anak mampu menggunakan kata dalam bentuk jamak, awalan, akhiran. Anak mampu mengkritik, bertanya, menjawab, memerintah, memberitahu, dan bentuk lain untuk satu pembicaraan gaya dewasa.

Perkembangan bahasa anak usia empat sampai lima tahun adalah (1) berbicara lancar dengan kalimat sederhana; (2) menyebutkan sebanyak-banyaknya nama benda, binatang, tanaman yang mempunyai warna, bentuk, atau menurut ciri-ciri tertentu; (3) bercerita tentang kejadian di sekitarnya secara sederhana; (4) mengurutkan dan menceritakan isi gambar seri (2-3 gambar); (5) bercerita tentang gambar yang dibuat sendiri; (6) mengikuti $1 \mathrm{~s} / \mathrm{d} 2$ perintah sekaligus, dan (7) membuat sebanyak-banyaknya kata dari suku kata awal yang disediakan dalam bentuk lisan seperti; ma, mama, malu, marah, dan sebagainya.

Sedangkan untuk perkembangan bahasa anak usia lima sampai enam tahun adalah (1) menirukan kembali 2 s/d 4 urutan angka, urutan kata; (2) mengikuti 2 s/d 3 perintah sekaligus; (3) menggunakan dan dapat menjawab pertanyaan apa, mengapa, dimana, berapa, bagaimana, dan sebagainya; (4) bicara lancar dengan kalimat sederhana; (5) bercerita tentang kejadian di sekitarnya secara sederhana, (6) menceritakan kembali isi cerita sederhana yang sudah diceritakan oleh guru; (7) memberikan keterangan/informasi tentang sesuatu hal; (8) memberikan batasan berapa kata/benda, misalnya apakah rumah itu? (9) menyebutkan sebanyak-banyaknya nama benda, binatang, tanaman yang mempunyai warna, bentuk, atau ciri-ciri tertentu; serta (10) menceritakan gambar yang telah disediakan.

Program pembelajaran yang disusun merupakan gambaran secara utuh dan komprehensif tentang berbagai komponen yang terkait dengan pembelajaran bahasa daerah Gorontalo, yang meliputi: standar kompetensi, kompetensi dasar, tema/ sub tema/materi, media, dan evaluasi. Gambaran secara utuh dan komprehensif ini diharapkan dapat memberikan pedoman secara menyeluruh, serta secara operasional dapat membantu setiap pendidik PAUD dalam melaksanakan pembelajaran bahasa daerah Gorontalo, sehingga benar-benar dapat membantu pengembangan kemampuan berbahasa daerah Gorontalo bagi anak usia dini.

b. Materi pembelajaran bahasa daerah Gorontalo

Materi pembelajaran juga harus sesuai dengan karakteristik perkembangan anak usia dini yang dijabarkan berdasarkan tema-tema pembelajaran yang dikembangkan di lembaga pendidikan anak usia dini, yakni tema (1) Diriku, (2) Binatang, (3) Lingkunganku, (4) Tumbuhtumbuhan, (5) Kenderaan, (6) Alam Semesta, (7) 
Negaraku, dan (8) Budayaku. Setiap tema tersebut dijabarkan menjadi materi dengan menggunakan bahasa daerah Gorontalo. Materi pembelajaran dikembangkan dalam bentuk penguasaan kosakata serta percakapan sederhana sesuai dengan tematema dan materi pembelajaran bahasa daerah Gorontalo.

Materi pembelajaran dapat dikemas dalam bentuk bahan ajar. Bahan ajar adalah bahan-bahan atau materi pembelajaran yang disusun secara sistematis yang digunakan guru dan siswa dalam proses pembelajaran (Pannen dan Purwanto, 1994). Agar dapat digunakan secara efektif, bahan ajar hendaknya dilengkapi dengan gambar-gambar menarik terkait dengan materi pembelajaran.

Kematangan anak dalam mengamati gambar melalui tiga tingkatan, yakni (1) kemampuan melihat objek-objek di dalam gambar, (2) kemampuan menentukan objek-objek yang dilihatnya dalam gambar, dan (3) kemampuan menafsirkan dan menarik kesimpulan, dalam arti anak dapat menyimpulkan bahwa gambar itu mengandung cerita tertentu. Selanjutnya dijelaskan bahwa anak-anak mengalami tiga tingkatan perkembangan abilitet artistik, yakni (1) tingkat simbolisme, anak puas akan bentuk simbolis dari suatu objek; (2) tingkat realisme; dan (3) tingkat abstraksi, anak lebih memahami artistik yang sebenarnya (Hamalik, 1994).

Pendapat tersebut menggambarkan bahwa di samping faktor ketertarikan anak, penggunaan gambar juga sesuai dengan tingkat perkembangan anak usia dini. Anak-anak pada usia ini telah dapat menangkap pesan yang ada dalam sebuah gambar, bahkan mereka telah mampu memahami nilai artistiknya.

c. Pedoman evaluasi

Evaluasi dimaksudkan untuk mengetahui dan mengikuti perkembangan berbahasa daerah pada anak setelah melaksanakan kegiatan pembelajaran bahasa daerah Gorontalo. Kegiatan evaluasi penting untuk dilakukan, di samping dapat mengetahui dan mengikuti perkembangan berbahasa daerah pada anak usia dini, juga untuk menilai efektivitas kegiatan pembelajaran yang telah dilaksanakan. Evaluasi ditujukan untuk penguasaan kosa kata serta kemampuan bercakap-cakap dalam bahasa daerah Gorontalo. Dengan adanya pedoman evaluasi, maka pendidik dapat melaksanakan evaluasi secara tepat terhadap perkembangan kemampuan berbahasa daerah Gorontalo pada anak usia dini.

\section{PENUTUP}

\section{Kesimpulan}

Berdasarkan uraian sebelumnya maka dapat disimpulkan bahwa (1) usia dini merupakan masa yang tepat untuk membelajarkan bahasa daerah, mengingat anak usia dini memiliki potensi yang besar untuk belajar bahasa; (2) pembelajaran bahasa daerah, termasuk pembelajaran bahasa daerah Gorontalo pada anak usia dini perlu diselenggarakan secara sistematis dan terstruktur berdasarkan pedoman yang jelas, yang meliputi program pembelajaran yang sesuai dengan karakteristik perkembangan anak usia dini, materi pembelajaran yang sesuai dengan karakteristik perkembangan anak usia dini, serta panduan evaluasi yang dapat mengukur dengan jelas perkembangan kemampuan berbahasa daerah pada anak usia dini.

\section{Saran}

Mengingat pentingnya pelestarian bahasa daerah Gorontalo melalui penggunaan oleh anakanak sejak usia dini, maka dibutuhkan kebijakan resmi pemerintah pusat dan daerah yang mewajibkan pembelajaran bahasa daerah Gorontalo di lembaga pendidikan anak usia dini. Kebijakan lainnya yang dapat dilakukan seperti mewajibkan seluruh siswa SD, SMP dan SMA dan guru di daerah Gorontalo agar pada hari-hari tertentu menggunakan bahasa daerah Gorontalo dalam komunikasi di sekolah.

\section{DAFTAR PUSTAKA}

Baruadi, M. K. (2014). Pemartabatan bahasa gorontalo (suatu keprihatinan terhadap ancaman kepunahan). Disampaikan pada Pengukuhan Guru Besar Tetap Universitas Negeri Gorontalo, 11 November 2014.
Universitas Negeri Gorontalo.

Danim, S. (2008). Media komunikasi pendidikan. Jakarta. Bumi Aksara.

Degeng, N.S., \& Miarso, Y. (1993). Terapan teori kognitif dalam disain pembelajaran. Jakarta. 
Pusat Antar Universitas.

Depdiknas, (2002). Perkembangan belajar peserta didik. Jakarta, Dirjen Dikti.

Dewi, R. (2005). Berbagai masalah anak taman kanak-kanak. Jakarta: Departemen Pendidikan Nasional Direktorat Pendidikan Tinggi, Direktorat Pembinaan Tenaga Kependidikan dan Ketenagaan Perguruan Tinggi.

Fatma, (1994). Identifikasi pembelajaran bahasa daerah Gorontalo di SD se Kotamadya Gorontalo. PBS-STKIP.

Hamalik, O. (1994). Media pendidikan (cetakan ke VII). Bandung, Citra Aditya Bakti.

Hulukati, W. (1997). Pengembangan paket pembelajaran bahasa Gorontalo sebagai alternatif muatan lokal untuk kelas I SD di kotamadya Gorontalo. Tesis, IKIP Malang.

Hurlock, E. B. (1980). Development psychology: A life-span approach. Fifth Edition. McGrawHill, Inc.

Mulyasa, E. (2002). Kurikulum berbasis kompetensi, konsep, karakteristik, dan implementasi. Bandung. Remaja Rosda Karya.

Pannen, P., \& Purwanto. (1994). Penulisan bahan ajar. Jakarta. Pusat Antar Universitas.

Pasaribu \& Simandjuntak. (2002). Psikologi perkembangan. Bandung Tarsito.

Pateda, M., \& Pulubuhu, Y. (2008). Bahasa Indonesia di perguruan tinggi. Gorontalo, Viladan.

Percival, F dan Ellington. H. (1988). Teknologi pendidikan. Alih Bahasa: Sudjarwo. Jakarta: Erlangga.

Ramirez, N. F., \& Kuhl, P. K. 2016. Bilingual language learning in children. Institute for learning \& brain sciences. University of Wsahington.

Saylor, J. G. (1983). Curriculum planniing for modern schools. New York. Rinchart and Winston. Inc.

Suparti, I. (2004). Perkembangan dan pertumbuhan anak usia dini. Jakarta. Rajawali Press.

Undang - Undang Nomor 20 Tahun 2003 tentang Sistem Pendidikan Nasional 